\title{
Lugares da literatura e os sentidos dos lugares transnacionalização, deslocamentos e violência em Bernardo Carvalho
}

\author{
Maria Aparecida Rodrigues Fontes ${ }^{1}$
}

\begin{abstract}
Resumo: Com este artigo pretendo interrogar como os deslocamentos, sobretudo no âmbito do projeto de internacionalização da literatura, a partir de conceitos de transnacionalização e da multiplicação de temas ligados à violência, têm sido úteis ao mercado editorial e, de certa forma, menos favoráveis aos projetos de cultura nacional. Isto nos leva a indagar acerca dos lugares da literatura e dos sentidos dos lugares, de sua autonomia referente a outros modos de discurso, e da capacidade da ficção transnacional de se colocar em relação hipertextual com diferentes tecidos históricos sem destituir a obra literária da sua capacidade política de articulação sociocultural. Combinando, portanto, a ideia de deslocamento e estranhamento como um valor suplementar, que possibilita ajustar foco e perspectiva, veremos como Bernardo Carvalho, em $O$ filho da mãe, trata das questões relativas ao transnacional na literatura, através da abordagem de temas comuns às grandes cidades e aos territórios em guerra, cujas especificidades modelam e determinam o comportamento das personagens e suas relações dentro de uma estrutura social deteriorada pelos conflitos e pela violência.
\end{abstract}

Palavras-chave: Literatura Brasileira. Transnacionalização. Deslocamentos. Mercado literário. Violência.

\section{Introdução}

A interseção de diferentes espacialidades e temporalidades, resultado de um intenso movimento de desterritorialização e transculturalidade, encontra em um determinado território um ponto de convergência e sincronização, processo este relacionado ao que se convencionou chamar de hipercapitalismo do mercado e transnacionalização da cultura, da literatura e da economia. Esses deslocamentos têm-se revelado, contemporaneamente, úteis ao mercado editorial internacional, e menos favoráveis, de algum modo, aos projetos reveladores da cultural nacional. Pensar em transnacionalização da literatura implica interrogar acerca do nacional, da relação entre universal e particular, da autonomia do artista e das armadilhas do mercado, matéria que também diz respeito à identidade do discutido "caráter postiço, inautêntico, imitado" (SCHWARZ, 1987, p. 29) da vida cultural brasileira. Embora polêmico

\footnotetext{
${ }^{1}$ Doutora em Ciência da Literatura pela Universidade Federal do Rio de Janeiro. Professora/pesquisadora de Literatura Portuguesa e Brasileira do DiSLL, Università Degli Studi di Padova. Itália. E-mail: maria.fontes@unipd.it (Didtp://orcid.org/0000-0001-9023-2515.
} 
em certos aspectos, o texto de Roberto Schwarz "Nacional por subtração" (1987) problematiza a ilusão do conservadorismo da autenticidade e autonomia buscada na subtração. Se nos anos $1960^{2}$ a literatura brasileira procurava uma espécie de "genuinidade" e uma posição identitária dentro do cenário nacional e a padronização e a marca americana veiculadas pela comunicação de massa apareciam ao nacionalista como efeitos negativos da presença estrangeira, a partir dos anos 1980 entra em cena o sentimento de que a defesa das singularidades nacionais contra uniformização imperialista era um "tópico vazio" e nessa atmosfera global de unificação planetária o combate por uma cultura genuína fazia, no dizer de Schwarz, "papel de velharia"3 $(1987$, p. 33). De fato, a ruptura com a ideia nacionalista encerrava também uma postura conservadora, porque, segundo o autor, os globalistas alinhavam-se com poder como quem faz a revolução. Deste modo, se a fórmula nacionalista era mistificada e criticada pelos "modernistas da mídia", as questões relativas à imposição ideológica externa e à expropriação cultural eram efetivas. Acreditava-se que, ao eliminar o que era alheio ao Brasil, se chegaria ao específico da cultura nacional. Essa sensação de inautenticidade e, consequentemente, a busca de uma identidade em uma cultura periférica e dependente da imitação, já observadas também por Schwarz, em As ideias fora de lugar, apontavam para um sistema imperialista de ordem econômica e cultural que criava classes de exclusão (ou minorias silenciadas). Percebe-se, nessas reflexões, que o crítico buscava na denúncia formal das desigualdades o antídoto para o sentimento incômodo gerado pela condição de inferioridade e pela cópia dos modelos externos. Com efeito, útil a Schwarz, enquanto metáfora da subtração, a famosa frase machadiana de que o "influxo externo é que determina a direção do movimento" (ASSIS, 1994, p. 4) é ainda hoje menos inevitável do que naquele tempo, principalmente devido à aguda crise ideológica dos discursos humanistas e ao processo de globalização que dissolveram a ideia de nacional. Nas palavras de Schwarz, os "globalistas" comportavam-se "como acossados", ou integrantes da vanguarda heroica,

\footnotetext{
2 "A partir dos anos 60, repartiram-se os grupos entre os que aderiram a uma poesia [e prosa] mais politizada, crítica em relação aos rumos tomados pela sociedade brasileira, e os que somaram à vanguarda inspirada pelas pesquisas associadas à expressão visual e às artes plásticas. Os poemas de contestação foram publicados em cadernos chamados Violão de rua, e o movimento tormou esse nome. O vínculo com a música popular também não foi ocasional", havia, portanto, o compromisso da literatura com o político e o nacional. Veja-se sobre o argumento (ZILBERMAN, 1994, p. 69).

${ }^{3}$ Conforme Schwarz, a ênfase na dimensão internacional da cultura funcionava como pura e simples legitimação da mídia. Assim como os nacionalistas atacavam o imperialismo e eram lacônicos quanto à opressão burguesa, os antinacionalistas daquele momento assinalavam a dimensão autoritária e atrasada de seu adversário, "com carradas de razão", fazendo, no entanto, crer que o reinado da comunicação de massa fosse libertário ou aceitável do ponto de vista estético (1987, p. 34).
} 


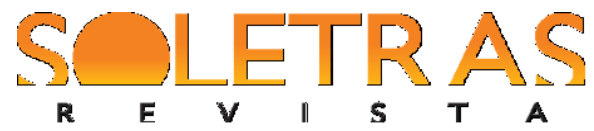

N. 38 - 2019.2 - MARIA APARECIDA RODRIGUES FONTES

estética ou libertária, do início do século. Os nacionalistas, mal ou bem, estavam ligados a conflitos que lhes davam visibilidade, enquanto os modernistas da mídia faziam supor um mundo universalista que não existia. Tratava-se, enfim, de "escolher entre o equívoco antigo e o novo, nos dois casos em nome do progresso" (1987, p.34).

Vinho novo em odres velhos, os deslocamentos, a violência e a alteridade têm sido os leitmotiven das narrativas transnacionais, sobretudo a partir da multiplicação dos espaços marcados pela descontinuidade temporal dos eventos históricos. Mas até que ponto a dissolução dessas fronteiras espaciais, somada à pluralidade temporal, não serve também para desviar o olhar dos problemas socioculturais e políticos brasileiros, distraindo o indivíduo com imagens e histórias exóticas e afastando-o das próprias vicissitudes? Se a dúvida ainda é pertinente (porque permanece), caberia, pois, indagar acerca da especificidade do literário e da sua autonomia em relação a outros modos de discurso, e da capacidade da ficção transnacional de se colocar em relação hipertextual com diferentes tecidos históricos e geoculturais, sem que essas relações constituam formas de manobra mercadológica de inserção no jogo de poder para legitimar um particular estilo literário contemporâneo ou para destituir a obra literária de sua capacidade política de articulação sociocultural.

Combinando, portanto, a ideia de deslocamento e estranhamento como um valor suplementar que possibilita ajustar foco e perspectiva, proponho examinar como Bernardo Carvalho, em $O$ filho da mãe, trata das questões relativas ao transnacional na literatura a partir da abordagem de temas comuns às grandes cidades e aos territórios em guerra, cujas especificidades modelam e determinam o comportamento das personagens e suas relações dentro de uma estrutura social deteriorada pelos conflitos e pela violência. Carvalho ficcionaliza os meandros dos regimes autoritários, sem desconsiderar que neles subjazem não somente a xenofobia, o preconceito e a exclusão - irmãos da intolerância e do horror -, mas o "animal homem" envolvido nas delicadas relações entre subjetividade e violência bestial. $\mathrm{O}$ escritor decide, por conseguinte, interpretar as experiências das famílias envolvidas com a segunda guerra da Tchetchênia, pondo em relevo o papel das mulheres (em especial das mães) no interior das estruturas patriarcais e autoritárias do Estado e da família, marcadas, ainda, pela ditadura dos mercados globalizados que vêm colaborando para o aumento das redes internacionais do crime e incitando a multiplicação dos conflitos tribais, das limpezas étnicas, do fanatismo religioso e identitário. 


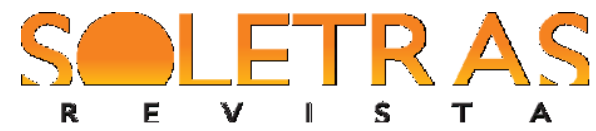

N. 38 - 2019.2 - MARIA APARECIDA RODRIGUES FONTES

\title{
Lugares da Literatura
}

Passados trinta anos da publicação do ensaio de Schwarz e de quando se efetivou a internacionalização do capital e a consequente mercantilização das relações socioculturais, a literatura brasileira incorporou definitivamente (sobretudo com a intensificação dos fluxos migratórios) os elementos entendidos como "corpo estranho" descaracterizadores da ideia de cultura nacional, produzindo uma quantidade expressiva de narrativas que apontam não apenas para a fluidez e a dissolução das fronteiras entre categorias sociais e para a vulnerabilidade do Outro, como também para uma heterogeneidade de vozes (vozes das ruas), espaços e tempos. Estaríamos, finalmente, nos tornando uma sociedade sem classes? Interroga Schwarz, em Sequencias brasileiras (1999), observando que essa multiplicidade não deixava de assinalar um "momento nacional”, ainda que vivido em escalas globais. A ficção brasileira, que abandonara seu tom de resistência política e ideológica, afirmou-se nesses últimos anos através de uma função política específica, i.e., "resistir a uma hierarquia ancestral em que predomina o discurso branco, masculino e cristão" (PELLEGRINI, 2008, p. 71), introduzindo, desse modo, outro viés temático ligado ao universo urbano, cujos atores sociais mulheres, negros, homossexuais tornaram-se protagonistas frequentes, expressando-se a partir de um lugar específico:

\begin{abstract}
A ficção brasileira contemporânea, tal como a poesia, posicionou-se perante questões candentes da cultura e da arte nacional. Optou por traduzir os problemas da sociedade, substituindo a voz do sujeito escritor pela do oprimido, e depois voltando ao início, quando oprimido era o próprio escritor. [...]. Com isso, foi possível vencer o dualismo legado aos modernos, porque, da representação do nacional, a literatura pôde dialogar com seus representantes, mostrar-se sua aliada e manifestar suas inquietações e necessidades numa linguagem em que os principais interessados, alçados à condição de sujeitos, se reconheciam (ZILBERMAN, 1994, p. 69). p. 76).
\end{abstract}

Este lugar, através do qual se estaria autorizado a falar, tornou-se, portanto, um espaço autônomo das práticas literárias da primeira década do século XXI, reconduzido e reformulado pela consolidação tanto do mercado editorial global, que passou a garantir a autonomia financeira do escritor brasileiro, quanto da indústria cultural, da qual emergiu também outra tipologia de ficção, aberta à internacionalização, cujo enredo transnacional deslocou-se para ambientes fora do Brasil. $\mathrm{Na}$ impossibilidade de reconciliação entre a 
experiência e a narração, o vocábulo "ambientado" parece, pois, o termo justo para esse tipo de ficção que não resulta da análise ou experiência do autor/narrador, mas de sua "observação" (no sentido benjaminiano do termo), colaborando para o progressivo abandono da intencionalidade de intervenção política e ideológica da ficção.

Escritas para um público cada vez mais heterogêneo, tais narrativas criam uma assimetria espaço-temporal que estabelece uma discrepância geográfico-cultural entre a memória "nacional" do escritor (e/ou emigrante) e a cultura do país de destino, instaurando, consequentemente, uma fissura na elaboração da geografia literária e da representação cultural e identitária. De um lado, reforçam, sem dúvida, o efeito documental desse sistema e as linhas de forças e de poder no interior dessas culturas, em geral híbridas; de outro, estabelece uma geografia cultural que torna difícil a (re)produção de uma historiografia literária, tanto nacional quanto comparada, ou a (re)configuração de traços identitários individuais e coletivos. Este fato já tinha sido antecipado por Heloísa Buarque de Holanda, quando apontou o crescimento das cidades e o interesse pela realidade urbana como causas para o encerramento do ciclo nacional da literatura brasileira, permitindo aos escritores rever as questões de fronteiras e de espaços.

A compreensão do que seria uma temática nacional variou no tempo e no espaço, como bem lembrou Regina Zilberman (2010), o próprio Machado de Assis, no texto "Instinto da nacionalidade", rebelou-se contra a noção de que indígenas e cor local fossem as únicas opções aos escritores, e tratou de percorrer uma estrada independente. Para além do exercício da cor local, a autora observa que a literatura brasileira sempre conseguiu ultrapassar o exotismo de um Jorge Amado, por exemplo, lidando com temáticas de cunho social, político e étnico, experimentalista e metaficcional historiográfica, cuja atenção voltada à especificidade da vida nacional não prejudicou a leitura dos autores brasileiros fora de seu país de origem (ZILBERMAN, 2010, p. 197). Mas o problema agora é outro, não há mais especificidades nacionais nas narrativas ditas globais, que hoje ultrapassam qualquer fronteira e que se tornam, elas mesmas, objetos de transplante, redimensionando as relações entre literatura e seus lugares, os lugares da literatura e a literatura do lugar. Não é sem razão que as grandes metrópoles e os países exóticos se tornaram palco para narradores que assumem um compromisso com histórias e realidades globais tendo como leitmotiven os efeitos da violência e a miséria humana. Pascale Casanova observa, entretanto, que: 
Chaque espace national (par conséquent, dans la sphère littéraire, chaque écrivain qui en porte la marque) est fortement défini par la place qu'il occupe dans la structure mondiale dans laquelle il est affronté à toute la structure du pouvoir telle qu'elle s'offre au moment de l'observation (CASANOVA, 2011, p. 21).

A fabricação de uma literatura universal, desde a internacionalização literária à globalização comercial, está relacionada também à construção dos meios e órgãos legitimadores desses lugares da literatura. De fato, em 2017, nasceu em Paris, a "Associação Língua Franca", centro de legitimação e de aquisição de capital literário europeu, uma sorte de agência de literatura transnacional cuja finalidade é a criação de um espaço transliterário, a partir do que Pierre Levy denominou de inteligência coletiva, que consiste em privilegiar o texto restituindo-lhe a voz que lhe é própria para além da sua língua de origem.

Dito isso, as narrativas de Bernardo Carvalho, produzidas sobretudo para um público internacional, em especial aquele francês para o qual o autor tem sido traduzido, devem ser analisadas com especial atenção. Essas narrativas alinham-se às especificidades do "romance global" que recompõem e interpretam os sentidos dos lugares, muitas vezes de modo incompleto e precário. Em seus romances, principalmente em Teatro (1998), Nove noites (2001) e Mongólia (2003), O sol se põe em São Paulo (2007) e O filho da mãe (2009), Carvalho, além de conjugar relatos de viagens à ficção, organizada em parte por fontes históricas e observações pessoais, cria superposições de representações culturais e espaciais, inserindo uma história dentro da outra, nem sempre convincentes ou congruentes com a realidade local, que é sempre resultado de uma diegese interna. Em Mongólia, os personagens nômades aproveitam da visibilidade de um mundo globalizado para negociar a imagem de estrangeiro, movendo-se de modo a não deixarem rastros, apagando as relações entre causa e consequência dos eventos. Em nível diegético, a errância dos personagens advém, portanto, da negação de um referente, da proliferação do espaço na literatura, da literatura no espaço, do esvaziamento progressivo da memória e, consequentemente, da destemporalização do espaço social que se multiplica em instantes desconexos.

Emerge ainda desse contexto, a disputa pela inserção no mercado internacional, que, como bem notou Tânia Pellegrini, implica "transformações significativas do código estéticoliterário, que aos poucos incorporou como naturais - com habituais exceções -, descuidos, mesmices, obviedades e redundâncias na fatura, em busca de leitores" (2008, p. 200), sem 
falar dos clichês ligados a expressões referentes ao vocabulário da globalização, comuns em muitos best-sellers. Algumas dessas estratégias de marketing tornaram-se evidentes quando, nas coleções de literatura estrangeira, as formas de universalização e escolha para a publicação dos romances passaram a variar das mais politizadas àquelas despolitizadas. A diferença entre ambas as opções consiste na avaliação do mercado em relação à recepção da obra, pautada na hierarquia de classe e no nível de instrução: a primeira "sublinha a dimensão histórica e memorial da literatura, e a segunda valoriza as qualidades literárias da obra, a sua dimensão autorreferencial, ou ponto de vista autodiegéticos de experiências que podem ser partilhadas para além das fronteiras geográficas ou temporais, sem considerar qualquer particularismo" (SAPIRO, 2008, p. 207).

Com efeito, um dos temas que se repetem nas narrativas de Carvalho, além do nomadismo e da necessidade de interrogar "quem somos e para onde vamos", é a relação com o Outro que vai além dos limites da cultura ocidental e dos particularismos. Ocupam um lugar especial as personagens de nacionalidades diversas, índios Krahô do Xingu, orientais budistas, japoneses, russos, tchetchenos, migrantes em contínuo movimento. Trata-se de personagens investidas pelos signos do trânsito, da incompletude, da contradição e da violência, que, além de compor o cenário multiétnico ligado ao olhar deslocado e oblíquo desse "autor-viajante" ${ }^{4}$, contrapõem-se àquelas construídas pela nova geração de autores naturalistas que "falam de si”. Uma invenção que, na opinião de Carvalho, não passa de um verniz ou de um efeito publicitário, determinado pela crítica à literatura do artifício que agradaria apenas uma elite econômica do país desvinculada da realidade. Nas palavras do autor de Mongólia, esse tipo de naturalismo militante e "a deficiência da malha social no Brasil" induzem, para além da "dificuldade de engolir" essas "vozes das ruas", uma máconsciência e reduzem as possibilidades de compreensão da literatura não enquanto produto independente da sociedade em que é criada, mas partindo sempre da obviedade que toda literatura é consequência do lugar e do tempo em que é criada, de entendê-la mais como

\footnotetext{
${ }^{4}$ Os romances Mongólia (2003) e O filho da mãe (2009) fazem parte desse mecanismo que se tornou muito comum não só no Brasil como em Portugal. O primeiro romance é resultado de uma bolsa destinada ao projeto "Autor-viajante", concedida pela Fundação Oriente, de Lisboa, a Bernardo Carvalho, que viajou para Mongólia, o que condicionou a composição do cenário narrativo. O segundo foi financiado pelo projeto "Amores Expressos", que convidou escritores a viajar para lugares exóticos com o compromisso de escrever, posteriormente, um livro de ficção - uma história de amor no cenário de viagem - e sobre as "experiências" vividas. Este projeto levou mais de 17 escritores a 17 cidades pelo mundo, cujos romances vêm sendo publicados pela editora Companhia das Letras, entre eles destacam-se: Estive em Lisboa e lembrei de você, de Luiz Ruffato (2009), O único final feliz para uma história de amor é um acidente, de João Paulo Cuenca (2010), O livro de Praga, de Sergio Sant'Anna (2011), Ithaca Road, de Paulo Scott (2013).
} 
possibilidade de invenção do que como documento histórico e sociológico, que de qualquer modo ela sempre é, a priori (CARVALHO, 2005, p. 218). Em outras palavras, o que estaria em jogo seria tanto a "pseudoautonomia" do artista promovida pelo capitalismo quanto a velha contenda entre "nacionalistas" e "globalistas".

Com efeito, libertando-se das "encomendas ostentatórias", o escritor passa a não mais depender de patrões nem "multiplicar topoi reconhecidos" (COSTA LIMA, 2004, p. 104). Entretanto, se o mercado possibilitou a autonomia da arte, também a transformou em mercadoria, atribuindo-lhe "valores de troca", adequando-a à recepção e ao gosto do público. O problema atual relacionado à produção artística e literária é que ambas as manifestações não podem prescindir do mercado, exceto naqueles casos, como assinalou Costa Lima, em que o artista é diretamente comissionado por uma instituição pública ou privada, o que, dentro das relações capitalistas, é apenas uma solução contingente. A autonomia artística termina por exercer, dessa maneira, "um efeito boomerang: a obra autonomizada ou perde sua especificidade, convertendo-se em mercadoria ao lado de outras, ou tem decretada sua inutilidade" (2004, p. 108).

De fato, a emergência de projetos de publicação sob encomendas, por meio de bolsas de pesquisa, residências, concursos, feiras literárias ou de viagens e de séries temáticas de livros, além de evidenciar esse efeito perverso da pseudoautonomia e dissolver os particularismos na ficção - a literatura dos lugares -, mostra a vitória não dos escritores, mas do mercado que, ao estimular tais programas, obriga o autor a limitar o seu tema a um contexto global, determinado por uma lógica mercadológica e por programas de internacionalização que, em geral, amarram a estrutura ficcional: a) a esquemas que venham ao encontro da crítica do momento e das reivindicações teóricas e estéticas; b) a uma diversidade de público classificada de acordo com os objetivos dos editores e as cotações/business do mercado; c) à compreensão de uma realidade não de tudo verossímil e, muitas vezes, atrelada a outra noção de real percebida como improvável, trágica e inumana ou como destino irremediável. Um bom exemplo é a frase do personagem Buruu Nomton, um dos narradores de Mongólia que, ao confrontar-se com outra realidade, identifica no nomadismo não mais a abstração filosófica de um tempo, tampouco um modo de vida alternativo e libertário, mas uma forma de vida fixa e repetitiva (CARVALHO, 2003, p. 132). Entretanto, como bem escreveu Costa Lima: 
[...] a representação, especialmente neste tipo de estrutura, não tem nada a ver com o correlato textual de cenas percebidas ou de seres fantásticos previamente aceitos [...] porquanto também contém o modo como o receptor suplementa os "lugares vazios" que estão na obra literária (e artística). Ora, esse papel ativo reservado à representação é exacerbado pelo caráter da arte autonômica. Porquanto ela rompe com os modelos da tradição clássica, ela escava seu "germe anímico", sem concessões ao já sabido e esperado. Deste modo, ela tende a se chocar com seus receptores - o receptor, aí incluindo o próprio expert, temeroso de suas próprias respostas ou do imbróglio que possam causar à sua maneira de viver a vida (2004, p. 115).

O acesso democrático das literaturas periféricas às dinâmicas mundiais de difusão da cultura constitui outro problema, porque é ainda hoje inexistente, o que não só alimenta a disputa e rivalidade entre escritores na defesa do global ou do particular, como também contribui para a exclusão, pelo mercado editorial, da possibilidade de trocas equitativas de conhecimentos e de diálogo entre classes minoritárias, publicando livros que tratam sempre dos mesmos temas, induzindo novos comportamentos críticos, ditando moda. Igualmente, o perfil dos escritores tende a se repetir, e seus livros, resenhados por críticos famosos de grandes jornais, são distribuídos por livrarias nacionais e internacionais que lhes imprimem a chancela de literatura brasileira, negligenciando outras vozes periféricas que não têm acesso a esse circuito ou que não estejam de acordo com a linha estética do momento.

\section{A literatura entre lugares}

Tendo como cenário a segunda ocupação do território tchetcheno pelos Russos, Bernardo Carvalho, em $O$ filho da mãe $e^{5}$, vai tratar das histórias de dois rapazes: Ruslan que, abandonado pela mãe ainda criança e cujo pai fora assassinado durante os conflitos entre Russia e Tchetchênia, foge da cidade de Grózni, território ferido de guerra, para São Petersburgo onde trabalhará nas obras do tricentenário da cidade. Andrei, filho de uma russa com um exilado político brasileiro, obrigado a ingressar no exército russo, transfere-se de Vladivostok, a importante cidade portuária da Rússia à beira do pacífico, a São Petersburgo. Cidade em que ambos os personagens encontrarão o amor e a morte, embora as ações não se

\footnotetext{
${ }^{5}$ Uso aqui a edição Ebook: CARVALHO, B. (2009), portanto indico a posição e não as páginas, considerando a medida n. 1 dos caracteres indicada no display.
} 
limitem a esse espaço, deslocando-se do Oiapoque ao Nieva, De Grózni ao mar do Japão. Marginalizados, explorados e vivendo em condições inumanas os conflitos de quem é abandonado pela família, refugiam-se, à noite, em espaços degradados da cidade, cometendo furtos e delitos.

Relegando a história de amor entre Ruslan e Andrei ao segundo plano, o autor apresenta o mundo da guerra através de diferentes vozes e olhares femininos, do discurso das mães e das várias representações da maternidade, tendo a relação mãe e filho como um dos eixos centrais da narrativa. Mães que perderam seus filhos para guerra, outras que tentaram salvá-los do massacre ou do inferno de servir ao exército; mães que perderam suas crianças inermes, vulneráveis, assassinadas sem piedade pelas forças militares. Mães que abandonaram seus filhos à própria sorte, ao destino trágico. É o caso dos núcleos familiares de Anna e Olga, mães que ainda mantinham o domínio simbólico sobre seus filhos, inclusive o poder de destruí-los.

No passado, Olga fora casada com Alexandre, um brasileiro exilado em Moscou, e dessa união nascera Andrei. Quando o filho completou nove anos, o pai resolveu voltar para o Brasil, mas Olga não quis acompanhá-lo. Um ano depois ela conheceu Nikolau e casou-se novamente. $\mathrm{O}$ filho cresceu e as brigas entre o padrasto e o enteado tornaram-se frequentes, até o dia em que Nikolau, depois de lhe dar um soco na cara, exigiu que o rapaz saísse de casa e não aparecesse na sua frente enquanto não pudesse se sustentar (CARVALHO, 2009, p. 1952). Com o segundo casamento Olga não conseguiu substituir a figura paterna, e a autoridade do padrasto era sempre posta em causa, porque Andrei não via nela a figura parental, carecia tanto de legitimação como de reconhecimento do direito de exercer a função de autoridade, sobretudo porque essa autoridade era desprovida de afeto. Quanto mais o padrasto procurava intervir na educação e na vida do enteado, mais frequentes eram os conflitos entre eles. A mãe e a irmã, em prantos, procuravam interceder em favor de Andrei, mas eram impedidas por Nikolau que berrava: "Ele vai ter que aprender, como eu aprendi" (CARVALHO, 2009, p. 1952). Olga, por medo de se separar novamente, não conseguiu impedir que o filho fosse expulso de casa, nem que fosse parar no exército russo, tomou partido do marido e manteve-se passiva e omissa. A única ajuda que conseguiu oferecer ao filho foi viajar até Moscou em segredo, aproveitando a ausência do marido, para providenciar o passaporte de Andrei e entregá-lo à Marina, em São Petersburgo, que organizaria a viagem 
do rapaz para encontrar o pai no Brasil, de modo a livrá-lo dos maus-tratos da família e dos frequentes estupros aos quais era submetido dentro do exército russo.

A recontextualização da história cultural e das tradições familiares descritas pelo narrador heterodiegético revela-se na conivência de Olga com o autoritarismo agressivo do marido, em particular quando ela abandona o filho à própria sorte como solução para a manutenção do casamento e da paz familiar. A revolta de Andrei, dessa forma, não era tanto contra o padrasto, mas contra a submissão da mãe, contra a obediência cega às ordens daquele que se colocava na posição de autoridade familiar e no pretenso lugar do pai. A omissão e a inércia foram os modos através dos quais se manifestara em Olga o poder simbólico que se inscreve nas coisas e nos corpos, a partir da cumplicidade, da adesão do dominado ao dominante, e dos discursos paternos que, segundo Bourdieu (2009), têm um "efeito mágico" de constituição e nominação criadora do sujeito porque fala diretamente ao corpo. Todavia, a violência que se evidencia no interior das famílias não é específica da cultura russa ou caucásica, mas verifica-se em qualquer outra sociedade e, sobretudo, nas relações familiares brasileiras ou naquelas em que há multiplicidade étnica. Assim, a diegese apenas nomadiza a trama e os espaços vividos, operando uma reescrita do espaço geopolítico e cultural, tentando encontrar correspondência entre histórias locais e globais, na transnacionalidade dos argumentos e na generalidade da organização social, marcada, em especial, pela presença de comunidades de imigrantes, de estrangeiros que ali residem ou trabalham.

No romance, os juízos de valor da pátria potestas que contribuem para modelar as vocações e os corpos, provêm desse sujeito global, que, tendo sido ele próprio modelado pelas necessidades (porque herda essa tradição cultural), tem no princípio de realidade o princípio de prazer (BOURDIEU, 1998, p. 86). O consenso e a cumplicidade de Olga anulam a responsabilidade de seus opressores - Alexandre e Nikolai, figuras tipificadas, ausentes e fantasmagóricas na narrativa - que põem em seus ombros a obrigação do ato de responder pelo filho. Olga, então, sucumbe, experimentando o sentimento de fracasso, covardia e assumindo toda a culpa pelo trágico destino de Andrei, porque, na concepção generalizada da voz narrante, é a mãe a principal figura parental quando "os recrutas pedem socorro" (CARVALHO, 2009, p. 1396). A violência também se repetia dentro do exército, e no seu íntimo, o rapaz, obrigado a prostituir-se, sabia "que sempre haver[ia] alguém pronto para reconhecer e atacar a vulnerabilidade onde quer que ela se manifest[asse]" (CARVALHO, 2009, p. 1491). 


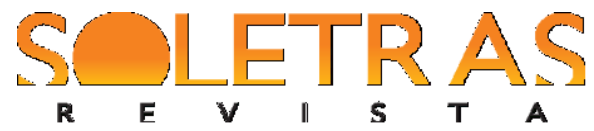

\section{N. 38 - 2019.2 - MARIA APARECIDA RODRIGUES FONTES}

Levado pelo senso comum, o narrador insinua que caberia à figura da mãe manter, proteger, cuidar e, sobretudo, interceder pelo filho, salvá-lo ou destruí-lo. Por isso, a punição do padrasto residia menos no fato de ter mandado Andrei para o exército do que lhe ter roubado o amor e a proteção da mãe pelo vulnus. Porque, segundo a lógica hobbesiana cínica e impiedosa, se a mãe quiser abandonar o filho, ou expô-lo à morte, qualquer um que o encontrar nessa situação, exposto à própria sorte, terá o mesmo direito àquilo que é concedido à mãe diante da vulnerabilidade do filho no momento em que se põe a alternativa entre cura e violência. Trata-se de uma forma cínica de mostrar a precariedade e a vulnerabilidade das personagens à deriva pelos espaços urbanos contemporâneos, desconectados das relações familiares de afeto e da ordem de direito do Estado.

Ao transitar entre o particular e universal, a estratégia de Bernardo Carvalho é deslocar, no espaço e tempo, temáticas possíveis de acontecer em qualquer lugar do mundo, em diferentes momentos epocais, reivindicando para a literatura o lugar do artifício, estruturada a partir de uma linguagem impessoal, desinteressada, que, além de criticar as identidades fixas e estáveis, não consegue dialogar com o mundo das coisas, pondo em jogo a dificuldade da comunicação humana e, acima de tudo, de relacionar os eventos numa sequência de causas e efeitos. Assim, as histórias sobrepõem-se devido à multiplicidade de espaços e ao enredo labiríntico, obrigando o leitor a percorrer caminhos sinuosos. O autor traça linhas itinerantes, sem definir as fronteiras, em um ir e vir, viajando através de tempos descontínuos e por espaços dobrados. Há uma perda de sentido da continuidade histórica enquanto estratégia geopolítica e cultural que revela o empenho do intelectual e do escritor em trânsito, cônscios de viver um desdobramento identitário ao configurar uma rede de diálogos-interpretantes. O olhar desenraizado é, para Bernardo Carvalho, uma forma de afastar-se tanto dos parâmetros que procuram refletir, retratar e forjar uma imagem do Brasil como algo essencial e obrigatório, quanto da ideia de literatura nacional, comprometida com uma realidade brasileira. O espaço da Weltliteratur configura-se, para o autor, enquanto lugar no qual coexistem vários textos incorporados e incompletos, um espaço textual capaz de acolher o outro, tal qual um "hotel” que, como estrutura de passagens, é íntima e estrangeira ao mesmo tempo. Assim, o espaço é girado, sofre uma torção que determina um continuum trânsito entre o que é externo e interno. 


\section{O sentido dos lugares}

Paralelamente à história de Olga, desenrola-se, na parte meridional da Rússia, em território tchetcheno, os dramas de Anna que, segundo suas próprias convicções, fora educada para ter um objetivo na vida. Desde pequena falava francês como o seu avô, médico letrado e homem de outra época, mas Anna perdeu-se no dia em que conheceu Chakhban. Conheceram-se no ônibus e Anna "esqueceu que estava à espera de um marido russo que lhe pudesse assegurar os privilégios que a sua educação exigia" (CARVALHO, 2009, p. 472). Ele era uma infeliz interrupção no projeto de vida de uma moça inteligente, culta e promissora. Chakhban, o pai de Ruslan, formou-se em Química em Leningrado, onde conheceu Anna e, por ela, abriu mão de seus projetos de vida, tornando a Grózni para cumprir um desígnio maior, construir uma família em seu país; lá chegou com a mulher grávida. Ela, sem vocação para a maternidade precoce, porque "nem toda mulher quer ser mãe", foge dois meses após o nascimento do filho Ruslan, abandonando-o aos cuidados da avó. Anos mais tarde, Zainap explicava ao neto que não eram todas as mães que amavam, desde o início, seus filhos, (CARVALHO, 2009, p. 489), tentando justificar o gesto de Anna e convencer o rapaz a deixar a cidade e partir para São Petersburgo, primeiro para fugir da guerra e procurar trabalho, depois para encontrar o que nunca tivera: a mãe.

Zainap tinha vivido no Cazaquistão e, em 1959, um ano depois de começarem a repatriar a diáspora tchetchena, tornara a Grózni com o filho de um ano, sendo obrigada a criá-lo sozinha. A história repetia-se, haveria de crescer igualmente o neto e salvá-lo da guerra e da miséria. Anna tinha vindo à Grózni para se livrar do amor, “As mulheres nascem para um amor que é insustentável e que passam a vida tentando compensar com amores secundários, para não ficarem loucas" (CARVALHO, 2009, p. 489), relatava a avó de Ruslan, refletindo sobre a morte do próprio filho Chakhban e o motivo pelo qual "as mães matam os filhos ao nascer”. Com efeito, Anna foge, deixando para trás o companheiro tchetcheno e, para se assegurar da possibilidade de um futuro marido russo, preservando-lhe a honra e a virilidade, abandona também o filho tchetcheno - filho do inimigo, da vergonha e da desonra. Se a virilidade masculina deve ser confirmada pelos outros homens, na sua veracidade violenta ou na sua potência, certificada pelo reconhecimento de pertencer a um grupo forte de homens verdadeiros, ela, no entanto, não pode ser aviltada, ridicularizada pela mulher, mas confirmada e preservada. A estratégia que Anna encontrou para preservar a virilidade do atual 


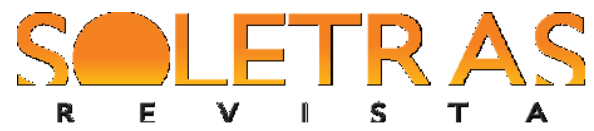

N. 38 - 2019.2 - MARIA APARECIDA RODRIGUES FONTES

marido e o pacto matrimonial, o que lhe assegurava o capital simbólico proveniente de uma família socialmente respeitada na sociedade russa, foi esconder e negar a existência do filho bastardo. Essa exaltação dos valores masculinos, na narrativa de Carvalho, encontra seu correlato no medo, na angústia e na fragilidade que feminilidade, enquanto encarnação da vulnerabilidade da honra feminina, exposta sempre à ofensa, ainda suscita em qualquer parte do mundo. A mudança drástica da trajetória das personagens, embora localizada historicamente no drama da segunda guerra da Tchetchênia, não encontra evidências diretamente na realidade externa, mas é resultado de uma mímesis interna à própria ficção. Assim, os arquétipos sociais e a realidade circunstante funcionam menos enquanto justificativas para os paradoxos das condutas éticas e morais, para a violência e a errância das personagens que a suspensão dos sentidos que contradizem a lógica discursiva.

Contrapondo-se ao entusiasmo naturalista dos escritores brasileiros das últimas décadas, Carvalho critica o fato de se fazer da literatura "a carteira de identidade dessa sociedade", atribuindo-lhe o papel de documento histórico ou sociológico (CARVALHO, 2005 , p. 218). A tendência predominante de apreender a literatura como documento acabou introjetando uma distorção entre os autores, diz Carvalho. Hoje há uma tendência cada vez mais unívoca de refutar o artifício nas artes, em nome da "expressão da realidade", "a ideia de que a literatura é sempre artificio é, para esses escritores, um absurdo a ser combatido" (CARVALHO, 2005, p. 219), como se pudesse haver arte sem artifício. Nesse sentido, Carvalho não acredita numa arte transformadora de uma realidade degradada sem cair no populismo ou nas armadilhas do realismo sociológico. A recorrência da valorização da "voz das ruas", segundo o escritor, é resultado da busca de uma autenticidade "bruta" contra os artifícios literários e, por mais idealizada e construída que seja, ela passa a ser sinônimo de verdade, de engajamento político e de justiça social, sobretudo nos momentos em que a injustiça e a desigualdade se tornam mais escandalosas e estarrecedoras. É como dar voz aos oprimidos e aos injustiçados, "Mas o que se reproduz com as boas intenções e a máconsciência é uma mistificação que, por um lado, não resolve as injustiças e, por outro, cerceia a criação literária" (CARVALHO, 2005, p. 218. Grifo meu). Todavia, é exatamente essa ideia de tragicidade ligada a um mundo sem esperanças que Carvalho impõe às suas personagens, não há salvação nem no artifício, tampouco na beleza a que aludia Adorno. Há, em Carvalho, um tom nietzschiano, de modo que suas narrativas parecem propor a moral da bestialidade e da depredação, da história da inconsciência, a biologia do racismo, a política 


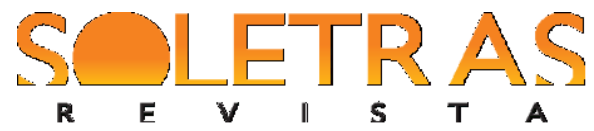

N. 38 - 2019.2 - MARIA APARECIDA RODRIGUES FONTES

dos Estados selvagens e a fisiologia dos instintos básicos. De fato, uma das cenas importantes do romance é o dramático reencontro entre Anna e Ruslan, entre mãe e filho. Em nome da economia dos bens simbólicos que ainda regem o sistema (universal) e as estratégias de reprodução e matrimônio, monopolizados pelos homens porque lhes asseguram a transmissão de poder, Anna renuncia à maternidade e renega o filho pela segunda vez, quando este vai procurá-la em São Petersburgo. A campainha toca, Anna abre a porta: "Ela sabe quem ele é, desvia o olhar, depois volta a fitá-lo por um instante, ao mesmo tempo surpresa e desconcentrada. Não consegue olhar para ele, tenta fechar a porta, mas não consegue. O olhar desamparado do rapaz a impede e ela vacila" (CARVALHO, 2009, p. 743-762). A cena repete-se pela segunda vez, e ela renega-o novamente, reconhecendo nele um inimigo, um agressor: "Anna olha para o filho que ela abandonou [...]. É um ódio cego, que ela projeta no rapaz na sua frente, mas que muitas vezes sentiu por si mesma" (CARVALHO, 2009, p. 1134).

Recordando a Ilíada, de Homero, não é a morte o fulcro da égide de Atena, como síntese figural, que repugna, paralisa e petrifica, mas o horror e toda a fenomenologia do medo relacionada a ela. Representada pela cabeça da Medusa, o fulcro da égide é a face mítica do horror, que assusta, petrifica e despe os guerreiros de qualquer gesto heroico, para depois restituir-lhes a imagem mais autêntica de seu crime ontológico. Nos olhos da górgona, eles encontram não somente a morte, mas a representação do inumano. $\mathrm{O}$ mito que tem o rosto de mulher encarna o horror que se mostra nos seus efeitos, i.e, alude a uma violência que, além de tirar-lhes a vida, desfaz a unidade figural do guerreiro, petrificando-o, desmembrando-o, decapitando-o. O horror refere-se principalmente ao rosto e aos olhos, estes como forma de expor-se ao Outro. Na verdade, é a Medusa quem faz do sujeito o espelho no qual, transformando-o em pedra, contempla a sua face horrível e se reconhece a si mesma. No encontro fatal, entre o guerreiro e a Medusa, entre a mãe e o filho bastardo, a reciprocidade do olhar é central: ver e ser visto, o desdobramento e especularidade do olhar: cada um se reconhece na singularidade do Outro. A Medusa alude a um tipo de humanidade particular, pois, embora tenha tido o próprio ser massacrado, continua viva para contemplar o ato inaudito de sua desumanização.

A história de Anna lembra outrossim a de Medeia que rejeita e mata seus dois filhos para se vingar da traição do marido. Ocupando o polo oposto ao ícone da Madonna, que encarna a representação da maternidade protetora - a mãe amorosa e intercessora -, Medeia e 


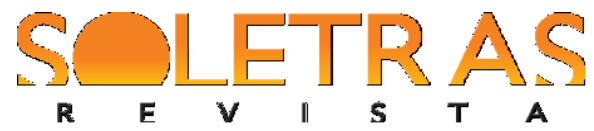

N. 38 - 2019.2 - MARIA APARECIDA RODRIGUES FONTES

Medusa são, ao contrário, a personificação do horror que se consuma num corpo (do outro) vulnerável e inerme. Ao abandonar pela segunda vez o filho, Anna torna-o ainda mais vulnerável e inerme à ira de Maksim, o meio-irmão que, por xenofobia e ciúmes, espanca-o até a morte, em uma cena extremamente cruel: "Com o braço sobre a cabeça [Ruslan] se protege como pode dos golpes que lhe desferem, enquanto gritam injúrias em nome da pureza do sangue e da pátria. Cai de joelhos já no quinto golpe [...]. Sua queda é acompanhada de um uivo" (CARVALHO, 2009, p. 2287).

Flora Süssekind denomina essas cenas na atual literatura brasileira de "Subjetividade e horror" (2005, p. 67), decorrente da proliferação "de híbridos, aberrações, figuras autodefinidas como monstros na literatura brasileira recente", monstros que, "se em diálogo direto com um contexto particularmente cruento, apontam, via figuração monstruosa, para uma lacuna epistemológica, uma desestabilização classificatória [...] da própria prática cultural" (SÜSSEKIND, 2005, 69) diante da afirmação de novas formas de organização das diferenças sociais em cidades pautadas por uma "homogeneidade globalizadora do espaço e por uma exacerbação do pânico da hetorogeneidade social" (SÜSSEKIND, 2005, p. 69).

Com efeito, a violência da cena revela-se ainda mais repugnante e radicalmente cruel porque ofende em nível ontológico a condição humana. Dmítre, marido de Anna e pai de Maksim, assiste ao massacre impassível, sem impedi-lo, ou - o que é mais repugnante ainda sendo cúmplice, porque consente que Maksim mate o "filho da mãe", considerado uma aberração, um hibridismo, uma quimera que, como tal, deveria ser destruída. Note-se que Maksim nutre ciúmes e ódio profundo pela mãe e quando descobre a sua relação secreta com Ruslan entrega ao pai a carta que o meio-irmão enviara à mãe e prepara uma cilada para matálo. Não é à toa que Maksim trai a confiança de Olga e a delata ao pai todo-poderoso, porque o corpo da mãe é sempre, e de algum modo, o corpo do incesto. A intervenção da função paterna no Édipo interdita-o e simboliza ao mesmo tempo. Assim, a imagem idealizada da boa mãe é dessubstancializada, revelando que para algumas mulheres a maternidade só pode ser vivida como fatalidade. Já o consenso e conivência do pai passam pela (in)comunicação humana que na sua dimensão constitutiva, como afirma Slavoj ŽiŽek "jamais requer um espaço de intersubjetividade igualitária [...] cada espaço discursivo, concreto, é baseado definitivamente em uma imposição violenta da parte de um Significante Dominante que é stricto sensu irracional" (2007, p. 66). Essa dimensão irracional atravessa uma outra semelhante cena de espancamento, vioência e crueldade, descrita por Aluísio Azevedo, no 


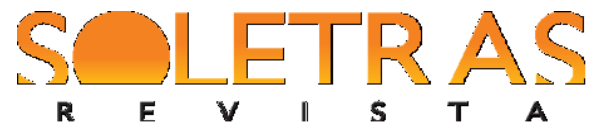

N. 38 - 2019.2 - MARIA APARECIDA RODRIGUES FONTES

romance naturalista $O$ Cortiço, quando o português Jerônimo, que havia sido internado em um hospital após a briga com o capoeira e mulato Firmo, arma uma emboscada traiçoeira para matar a pauladas o malandro e rival que, dias antes, lhe rasgara a barriga à navalha. Firmo representava os "capoeiras", perigosos e nocivos, um tipo sucessor dos vadios da colônia, eliminados da capital brasileira, porque, entre outros motivos, deveria ser afastado do convívio da elite:

\footnotetext{
Os dois vultos, pondo o cacete entre os dentes, apoderaram-se de Firmo, que bracejava seguro pelo tronco.

Deixara-se agarrar - estava perdido.

Soltaram-no então. O capoeira, mal tocou com os pés em terra, desferiu um golpe com a cabeça, ao mesmo tempo que a primeira cacetada lhe abria a nuca. Deu um grito e voltou-se cambaleando. Uma nova paulada cantou-lhe nos ombros, e outra em seguida nos rins, e outra nas coxas, outra mais violenta quebrou-lhe a clavícula, enquanto outra logo lhe rachava a testa e outra lhe apanhava a espinha e outras, cada vez mais rápidas, baliam de novo nos pontos já espancados, até que se converteram numa carga contínua de porretadas, a que o infeliz não resistiu, rolando no chão, a gotejar sangue de todo o corpo (AZEVEDO, 1890, p. 251-252).
}

A marginalização do "capoeira" pobre que vivia em cortiços tornou-se uma das estratégias de criminalização da pobreza, no Rio de Janeiro do final do século XIX e início do século XX, identificando socialmente esse sujeito como ser indesejável por motivo de alguma (hipotética) falta moral cometida. Retornando ao texto de Carvalho, os motivos que levaram ao assassinato de Ruslan não são muito diferentes. Não é por acaso que Maksim faz parte de um grupo de skinheads neonazistas, que tem aversão e ódio aos gays, estrangeiros, mestiços, sobretudo imigrantes do Cáucaso, de onde provém Ruslan que, aos olhos de Maksim, não passava de um "bunda-preta".

Igualmente, Marina Bóndareva e Iúlia Stepánova são importantes figuras femininas no romance de Carvalho. Marina é uma das responsáveis pelo Comitê das Mães dos Soldados de São Petersburgo a quem Iúlia recorre de modo a interceder junto ao comandante do exército na intenção de salvar um amigo hospitalizado devido a uma ferida de guerra. Chegando ao Comitê, reconheceu Marina, a amiga de escola, com quem, embora nunca tivesse tido tanta intimidade, acaba confidenciando-se. Iúlia não tinha filhos, estava com uma doença terminal. Marina, por sua vez, conta-lhe como perdeu o seu caçula, sequestrado por milícias tchetchenas e dado como morto. Ela partiu sozinha para Grózni e o encontrou vivo, negociou 
o seu resgate e o levou para casa. Mas não conseguiu salvá-lo. Um dia, quando entrou no apartamento, deparou-se com o filho pendurado no lustre da sala.

Iúlia, durante a conversa, relembra a avó, que contava ter conhecido a poetisa russa Anna Akhmátova ${ }^{6}$ na porta da prisão de Kresty, em Leningrado. A poetisa descreveu-a como a mulher de lábios azuis à espera do marido e do filho do lado de fora dos muros da prisão. $\mathrm{O}$ diálogo é interrompido pelo choro de Marina que, temendo não poder ajudar a amiga, confessa o seu fracasso por não ter conseguido salvar Andrei da morte, nas montanhas de Grózni. O rapaz que tinha sido abandonado pela mãe estava preste a partir para o Brasil quando, ao tentar defender uma mulher e seus filhos das atrocidades da guerra, fora assassinado pelo próprio companheiro do exército. A ficção cria uma atmosfera em que se confirma o horror enquanto forma peculiar de violência que não destrói somente os corpos, mas a dignidade humana, reduzindo os homens à animais, monstros, quimeras, como descrito na última cena: "Quando chegam [os soldados], a mulher está parada, segurando a espingarda, diante de um animal disforme e morto, um bezerro recém-nascido, ao mesmo tempo peludo e pelado [...]. Uma quimera, mistura de dois embriões, portadora de mau agouro" (CARVALHO, 2009, p. 2524). Esse desfecho faz de Andrei uma vítima exemplar, pois é exatamente a sua inocência e a sua estranheza, o paradigmático estatuto de ser o Outro - em um estado de dependência - que lhe consente desvelar o fundamento do horror no ato (in)voluntário da morte.

\section{Lugares indeterminados, espaço de conflitos}

O estado de guerra, que é apropriado para a legitimação da "exceção", instaura o processo de dissolução da norma e revela a "vida nua", que não é nem vida natural, nem vida social. Trata-se de um espaço político de exceção que é alimentado pela soberania, distinguindo-se do ideal liberal relacionado aos direitos dos cidadãos ao contrato social e ao

\footnotetext{
${ }^{6}$ As personagens Anna e Marina Bóndareva remetem-nos às poetisas Anna Akhmátova e Marina Tsvétaïeva que foram perseguidas pelo regime soviético e tiveram suas vidas marcadas pela tragédia. Anna Akhmátova cresceu sem pai, que a abandonou quando ainda era jovem, e casou-se com Nikolaj Stepanovič Gumilëv que foi executado em 1921 por causa de atividades consideradas antissoviéticas; teve o filho, o historiador Lev Gumilëv, preso diversas vezes, e isso a levou a uma intensa peregrinação aos campos de trabalhos forçados e prisões do regime de Stálin. Forçada ao silêncio, Akhmátova foi impedida de publicar suas poesias, exceto entre os anos de 1940 a 1946, e excluída da vida pública. Tsvétaïeva teve o marido, Serguei Efron, fuzilado, em 1941, e sua filha, Ariadna Efron, presa. Logo após o fuzilamento do marido e a prisão da filha, Tsvétaïeva suicidou-se.
} 


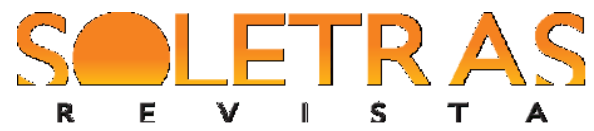

\section{N. 38 - 2019.2 - MARIA APARECIDA RODRIGUES FONTES}

seu livre arbítrio. Nesse território da guerra, a violência soberana exercita a sua vontade quando inclui, com exclusividade, a vida nua no Estado, abrindo-se para o processo de "lupificação do homem", cuja máxima hobbesiana é: "Homo homini lupus" (AGAMBEN, 2002, p. 113).

A homossexualidade de Andrei e Ruslan é um dos pontos chaves para se compreender os efeitos da violência numa zona de conflito entre diferentes e numa sociedade onde a heterossexualidade é compulsória. Os encontros sexuais entre eles aconteciam sempre em lugares escuros, abandonados e degradados, na periferia da cidade de São Petersburgo, onde não podiam ser identificados ou vistos, negando a própria identidade e, consequentemente, a sexualidade encarada como desvio e ilegítima. Estrangeiros, homossexuais, marginais, renegados pela mãe, filhos do inimigo e da guerra, Andrei e Ruslan são órfãos em trânsito indivíduos que, afetados pelos acontecimentos, se tornaram invisíveis aos olhos do Estado e para a história oficial. De fato, tantas vezes a exclusão não oferece outra saída senão através da automarginalização, da revolta violenta e da invisibilidade. Se o processo de individualização que caracteriza a atual conjuntura sociocultural adoça e ameniza os hábitos e os costumes da maior parte das pessoas, o contrário endurece os comportamentos dos delinquentes, marginais, desenraizados culturais, minorias raciais e sexuais, imigrantes (sobretudo jovens) que, confrontando-se com as próprias frustrações e com a desorganização sistemática de sua identidade, fazem da violência excessiva um meio de reconhecimento e de escape. A perda de rumo dos personagens, característica desse tipo de narrativa, mostra os indivíduos enquanto fantoches, envolvidos em intrigas e situações degradantes e inumanas. Isso confirma que violência nas figurações do urbano na literatura brasileira diz respeito "ao crescimento do crime violento e das reações igualmente violentas a ele, à generalização da sensação de risco e de conflito potencial, e à perda de sentimento de coletividade no cotidiano das grandes cidades" (SÜSSEKIND, 2005, p. 74). Trata-se também, no caso de jovens excluídos, de um "patchwork resultado do choque entre a recusa personalizada do enquadramento e a inserção tradicional; entre um sistema baseado no desejo individualista, na profusão, na tolerância e numa realidade cotidiana dos guetos, do desemprego, da ociosidade, da indiferença hostil e racista" (LIPOVETSKY, 1995, p. 229).

Estar fora e, ao mesmo tempo, pertencer: "é a estrutura topológica do estado de exceção" (AGAMBEN, 2004, p. 57), uma forma de exílio que não é nem um direito nem uma pena, não está nem dentro, nem fora da ordem jurídica, constituindo um umbral de indiferença 


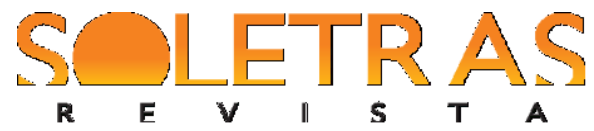

N. 38 - 2019.2 - MARIA APARECIDA RODRIGUES FONTES

entre o externo e o interno, entre a exclusão e a inclusão. Para Agamben, dentro e fora não se excluem, mas transformam-se em um lugar indeterminado (AGAMBEN, 2004, p. 39). Essa ambiguidade é o atributo do indivíduo exilado, excluído do Estado de direito, cuja vida se relaciona com a vida nua do Homo sacer, nem cidadão, nem estrangeiro. A narrativa de Carvalho recupera, assim, esses lugares subterrâneos, e deixa de ser apenas a ficcionalização da guerra para perscrutar a condição do exercício da subjetividade em áreas de diáspora e conflito, onde todos os personagens, independentes do sexo, estão perdidos em uma errância generalizada, onde os pontos de referência coletivos se dissolveram e a incerteza, a violência e a desorientação são constitutivas de um mundo privado de sentido. $\mathrm{O}$ que parece estar em jogo "é uma espécie de hibridação entre o cotidiano e o bestial, entre a perversidade e a vitimação, a paralisia e a aniquilação" (SÜSSEKIND, 2005, p. 70). É o mal como antídoto do mal. Talvez seja isso que emerge das reflexões de Z. Bauman (2012) ao tentar restabelecer uma ética capaz de criar um juízo apto a distinguir o bem do mal. O autor de Sfide dell'etica sublinha que a modernidade se funda no genocídio e se nutre do genocídio e da violência. Segundo autor, Auschwitz não é somente um evento histórico, mas o signo máximo da violência contra a humanidade, é um grande paradigma hermenêutico que serve a interrogar nosso ser e nosso destino. O mal não é passado, não é só um peso que carregamos em nossos ombros, ele está dentro de nossas relações intersubjetivas, surge até mesmo a partir do diálogo que o indivíduo solitário faz consigo mesmo. A guerra - a violência - não é apenas o indizível de uma situação extrema, é um elemento que tantas vezes se instala no vazio que se cala em nós e nas fraturas que se abrem no espaço social, às quais, segundo Rella, recebe o "nome de indiferença, ou opaca banalidade do mal" (2002, p. 103).

Essa criminalidade do social, que se instala na literatura brasileira e se transfere para um discurso em nível mais amplo e internacional, parece ter se acentuado, conforme Süssekind, no período de redemocratização política do Brasil, operando discursivamente por meio de classificações rígidas, estereótipos, segregações, recorrentes não apenas no noticiário policial jornalísticos, nas histórias individuais sobre assaltos, práticas de violência, homicídios, mas, igualmente, na produção literária dos últimos decênios, que reterritorializa, em vocabulário criminal conhecido, um novo padrão de organização das diferenças sociais no espaço urbano. Esses argumentos funcionam como interlocutores particularmente críticos da má experiência citadina de violência, instabilidade e segregação de alguns dos processos de 
desfiguração e desterritorialização, estruturais à literatura contemporânea (SÜSSEKIND, 2005, p. 66).

Se o espaço relacional, muitas vezes indeterminado, da Weltliteratur constitui o da literatura nômade que abre uma fissura no interior da literatura nacional para a inclusão do Outro e o hospeda em seu corpo, ele é, de igual modo, aquele que vai recolher toda a tipologia de discurso e conflito, inclusive o da violência. Note-se, nesse caso, que Carvalho apenas desloca o enredo para um outro lugar, conjugando-o a uma história de fundo, que é a segunda guerra da Tchetchênia, ignorando, todavia, vários aspectos históricos, políticos e culturais locais, menosprezando qualquer política de identidade. Sujeitos que se conectam com a história e a subjetividade por meio de fugazes e mutáveis processos de subjetivação construídos a partir do interior e não do exterior da representação, problematizando a questão relativa à autoridade e autenticidade que a expressão identidade cultural e nacional reivindica como própria.

\section{Considerações finais}

Nas narrativas de Carvalho, o transitório se expande em um eterno presente, não há um continuum temporal que prevê a transmissão contígua de tradições históricas ou de comunidades étnicas orgânicas. O que há são sobreposições e descontinuidades das categorias que definiam, até então, o conceito de cultura nacional homogênea. O fracionamento da estrutura da narrativa, em $O$ filho da mãe, dividida em duas histórias, ou dois blocos (quase) autônomos, recurso comum também em outros romances, funciona como um espectro ou negativo do outro, apagando as possíveis marcas identitárias de uma comunidade ou das personagens, efeito do processo de trasnacionalização e desterritorialização na literatura. Trata-se do (des)dobramento da escritura que mescla diferentes elementos e reutiliza formas diversas e heterogêneas de composição, possibilitando a convivência de vários planos e princípios dentro do universo diegético, sem hierarquia de valores estéticos, negando e cancelando também, através da fragmentação, as marcas da subjetividade, em um procedimento discursivo que reitera a incomunicabilidade e o esfacelamento da ordem do mundo contemporâneo. Um tipo de escritura que corresponderia à imagem do rizoma que cresce desordenadamente. Esta metáfora se estenderia tanto aos processos interdisciplinares 
nas áreas de conhecimento, quanto ao campo de abrangência do sistema literário e ao próprio lugar da literatura, exibindo a visão que se tem do presente como uma multiplicidade cultural infinita. Segundo esse princípio, os deslocamentos (entendidos também como nomadismo) seriam uma das condições para se atravessar o espaço rizomático, cuja superfície lisa contrapõe-se àquela sulcada da experiência, pois, conforme alguns teóricos da Weltliteratur, é essa capacidade de orientação que permite aceitar formas de identidade não codificada e de compreender as línguas não oficiais de raízes rizomáticas, línguas que dão vozes a novas identidades. O problema põe-se quando, ao apropriar-se desse espaço, o autor não o faz como instrumento de luta política, mas como um dos meios de entretenimento, agradável e despretensioso, palatável ao público e ao mercado.

Retomando o texto As ideias fora do lugar, de Roberto Schwartz, nas notas da reedição de 2014, o autor faz uma avaliação das páginas escritas entre 1969 e 1970, alegando que o tempo e os anos as desmentiram e, portanto, não mais seriam recomendas aos estudiosos da literatura brasileira. Contudo, resistindo a reescrevê-las, o autor observa que daquelas páginas alguma coisa resta, porque não se pode substituir os equívocos daquela época pelas opiniões de hoje, que podem não estar menos equivocadas e conclui: "Elas por elas, o equívoco dos contemporâneos é sempre mais vivo" (2014, p. 7). De fato, apagar os rastros deixados no território-nação é um ato de esquecimento e anacronismo, que não cancela as fissuras abertas dentro das fronteiras do nacional, ainda que esse "dentro" não passe de um sintoma, da configuração de um discurso imaginário sobre memória e experiência. Sendo assim, é importante insistir em uma literatura poliedra que consiga incluir os problemas do país e as diferenças, em detrimento da emergência da universalidade pós-nacional ou global guiadas por ações mercadológicas que, em geral, disseminam uma reflexão limitada sobre o mundo. Uma literatura que possa colher na experiência do Outro as perspectivas socioculturais e políticas, porque, como afirmava Machado de Assis, "Nem tudo é ouro nessa produção recente; e o mesmo ouro nem sempre se revela de bom quilate" (1994, p. 1).

\section{Referências}

AGAMBEN, Giorgio. Estado de exceção. Trad. Iraci D. Poleti. São Paulo: Boitempo, 2004. 
. Homo sacer: o poder soberano e a vida nua. Trad. Henrique Burigo. Belo Horizonte: Editora UFMG, 2002.

ASSIS, Machado. A nova geração. In: Obra completa de Machado de Assis. Rio de Janeiro: Nova Aguilar, v. III, 1994 [publicado originalmente na Revista Brasileira, v. II, dezembro de 1879]. Disponível em: http://machado.mec.gov.br/obra-completa-lista/item/download/91_d8 b5 f77c1aa58ad5f5bb8473b91b45f0. Acesso em 06 de jun. 2019.

AZEVEDO, Aluísio. O Cortiço. Rio de Janeiro: B. L. Garnier, 1890.

BAUMAN, Zygmunt. Le sfide dell'etica. 2.ed. Trad. Giovanna Bettini. Milano: Giangiacomo Feltrinelli Editore, 2012.

BOURDIEU, Pierre. Il dominio maschile. 2. ed. Trad. Alessandra Serra. Milano: Giangiacomo Feltrinelli Editore, 2009.

CARVALHO, Bernardo. O filho da mãe. São Paulo: Companhia das Letras/ Editora Schwarcz, Edição Kindler, 2009.

Minha cegueira (Depoimento). Literatura e sociedade, São Paulo, n. 8, DTLLC$\overline{\text { FFLCH, } 2005, \text { p. } 217-219 .}$

.. Mongólia. São Paulo: Companhia das Letras, 2003.

CASANOVA, Pascale (Ed.). La guerre de l'ancienneté ou il n'y a pas d'identité nationale. In: Des Littératures combatives. L'internationale des nationalismes littéraires. Paris: Raisons d'agir, 2011, p. 11-31.

COSTA LIMA, Luiz. A autonomia da arte e o mercado, ARS, São Paulo, v. 2, n. 3, 2004. Disponível em: http://www.scielo.br/scielo.php?script=sci_arttext\&pid=S1678-53202004000 300009. Acesso em 06 de jun. 2019.

LIPOVETSKY, Gilles. L'era del vuoto: saggi sull'individualismo contemporaneo. Trad. Paolo Peroni. Milano: Luni Editrice, 1995.

PELLEGRINI, Tânia. As vozes da violência na cultura brasileira contemporânea. In: Despropósitos: estudos de ficção brasileira contemporânea. São Paulo: Anablumme, 2008, p. 177-205.

RELLA, Franco. Figura del male. Milano: Feltrinelli, 2002.

SCHWARZ, Roberto. As ideias fora do lugar: ensaios selecionados. São Paulo: Penguin Classics; Companhia das Letras, 2014.

. Sequências brasileiras: ensaios. São Paulo: Companhia das Letras, 1999. p. $29-48$.

Nacional por subtração. In: Que horas são? São Paulo: Companhia das Letras, 1987, 
SAPIRO, Gisèle. Les collections de littérature étrangère. In: Translatio: le marché de la traduction en France à l'heure de la mondialisation. Paris: CNRS Éditions, 2008, p. 175-209.

SÜSSEKIND, Flora. Desterritorialização e a forma literária. Literatura brasileira contemporânea e a experiência urbana. Literatura e Sociedade, 10(8), 2005, p. 60-81.

ZILBERMAN, Regina. Literatura Brasileira contemporânea, a busca da expressão nacional. Anos 90, Porto Alegre, n.2, maio de 1994, p. 61-76.

. Desafios da literatura brasileira na primeira década do séc. XXI. Nonada, Letras em $\overline{\text { Revista }}$, n. 15, 2010, p. 183-200.

ŽIŽEK, Slavoj. La violenza invisibile. Trad. Carlo Capararo; Andrea Zucchetti. Milano: Rizzoli, 2007.

\title{
Literature places and the senses of places: transnationalization, displacements and violence in Bernardo Carvalho
}

\begin{abstract}
With this article I intend to question how displacements, especially in the scope of a literature internationalization project, based on concepts such as transnationalization and the multiplication of themes related to violence, have been useful to the publishing market and, to a certain extent, less favorable to national cultural projects. This leads us to inquire on literature places and the senses of places, their autonomy in relation to other modes of discourse, and the transnational fiction capacity to place itself in an interpersonal relationship with different historical fabrics without depriving literary work of its political capacity for socio-cultural articulation. Combining, therefore, the idea of displacement and estrangement as an extra value, which makes it possible to adjust focus and perspective, we will understand how Bernardo Carvalho, in $O$ filho da mãe, deals with issues related to transnationalization in literature, by approaching common themes to large cities and warring territories, whose specificities shape and determine character behavior and their relations within a social structure deteriorated by conflicts and violence.
\end{abstract}

Keywords: Brazilian literature. Transnationalization. Displacements. Literary market. Violence.

Recebido em: 11 de junho de 2019.

Aceito em: 07 de julho de 2019. 